\title{
Structural characteristics of tiller age categories of continuously stocked marandu palisade grass swards fertilized with nitrogen
}

\author{
Adenilson José Paiva ${ }^{1}$, Sila Carneiro da Silva ${ }^{1}$, Lilian Elgalise Techio Pereira ${ }^{1}$, Vitor \\ Del'Álamo Guarda ${ }^{1}$, Priscila de Mesquita Pereira ${ }^{1}$, Fábio Olegário Caminha ${ }^{1}$
}

${ }^{1}$ Escola Superior de Agricultura Luiz de Queiroz, Av. Pádua Dias, nº 11, 13418-900, Piracicaba, SP.

ABSTRACT - The objective of this experiment was to evaluate the structural characteristics of young, mature and old tillers on continuously stocked marandu palisade grass maintained at $30 \mathrm{~cm}$ and fertilized with nitrogen. Treatments corresponded to three nitrogen application rates (150, 300 and $450 \mathrm{~kg} / \mathrm{ha}$ of $\mathrm{N}$ ) plus control (no fertilization) and were assigned to experimental units $\left(1,200-\mathrm{m}^{2}\right.$ paddocks) according to a completely randomized block design, with four replications. Measurements were performed during fall/winter 2007 and summer 2008. During summer, young tillers showed longer leaves and shorter stems relative to old tillers. During fall/winter, young and old tillers showed shorter leaves, while mature and old tillers showed longer stems. Tiller age interfered with the number of leaves per tiller mainly through variations in the number of expanding and senescing leaves during both fall/winter and summer. The structural characteristics of individual tillers are affected by plant age, with nitrogen favouring the production of leaf tissue in young tillers during summer.

Key Words: Brachiaria brizantha, demographic profile of tiller population, morphogenesis

\section{Introduction}

Pastures are dynamic environments that respond to variations in climate and management through changes in processes at individual tiller and tiller population level. According to Lemaire \& Agnusdei (2000), the progressive and reversible change in morphology of plants in response to defoliation is defined as phenotypic plasticity, and characterise pastures as highly regulated systems where morphogenetic changes determine modifications in structural characteristics of individual tillers which, in turn, cause modifications in sward structure. Amongst the structural characteristics, sward leaf area index is highly correlated with both plant and animal responses (Sbrissia \& Da Silva, 2001), being, for that reason, the point of origin as well as the point of convergence of all modifications when swards are subjected to defoliation (Lemaire, 2001).

Sward leaf area index is formed by the combination of three structural characteristics; leaf size, tiller population density and number of live leaves per tiller. These, in turn, correspond to the phenotypic expression of morphogenetic characteristics in a given environment (rates of leaf appearance and elongation and leaf lifespan) (Lemaire \& Chapman, 1996). Amongst the management practices that determine the rhythm of phenotypic expression of morphogenetic responses, interfering with structural characteristics, nitrogen fertilization is certainly one of the most important. In recent years, the effect of nitrogen on structural characteristics of forage tropical grasses like mombaça guinea grass (Garcez Neto et al., 2002), massai guine grass (Martuscello et al., 2006), signal grass (Morais et al., 2006) and marandu palisade grass (Alexandrino et al., 2004) has been described. One of the most common responses is variation in tiller population density, as a result of modifications in patterns of tiller appearance and death (Cruz \& Boval, 2000). In general, the use of nitrogen fertilizer accelerates the appearance and death of tillers (Caminha et al., 2010), modifying the age profile of the tiller population in the area. Bullock et al. (1994) showed evidences that tiller age interferes with plant integrated physiological and morphological responses, altering their form and function at tiller and population level, causing temporal as well as spatial modifications in sward structure. According to those authors, plant age has a strong influence on the production of leaf tissue per tiller, which could result in larger accumulation of high quality herbage (Santos et al., 2006), suggesting the potential for manipulation of tiller population and its age profile as a means of increasing production and productivity of pastoral systems.

Marandu palisade grass is one of the most used grass species in cultivated pastures of Brazil. However, evidence regarding the effect of tiller age and nitrogen fertilization on 
its patterns of growth and development are scarce. Against that background, the objective with this experiment was to evaluate the structural characteristics of tiller age categories in continuously stocked marandu palisade grass maintained at $30 \mathrm{~cm}$ and fertilized with rates of nitrogen.

\section{Material and Methods}

The experiment was carried out in Piracicaba, state of São Paulo, Brazil (22 ${ }^{\circ} 42^{\prime}$ S, $47^{\circ} 37^{\prime}$ W and $550 \mathrm{~m}$ a.s.l.), on a fertile Eutric Kandiudalf soil, from Jan. 2007 to Apr. 2008. Average soil chemical characteristics (van Raij et al., 1986) for the 0-20-cmlayerwere: $\mathrm{pH} 0.01 \mathrm{MCaCl}_{2}=5.0 ; \mathrm{OM}=41.6 \mathrm{~g} / \mathrm{dm}^{3}$; $\mathrm{P}$ (ion-exchange resin extraction method) $=62.1 \mathrm{mg} / \mathrm{dm}^{3}$; $\mathrm{Ca}=60.7 \mathrm{mmol}_{\mathrm{c}} / \mathrm{dm}^{3} ; \mathrm{Mg}=16.0 \mathrm{mmol}_{\mathrm{c}} / \mathrm{dm}^{3} ; \mathrm{K}=6.6 \mathrm{mmol}_{\mathrm{c}} / \mathrm{dm}^{3}$; $\mathrm{H}+\mathrm{Al}=44.3 \mathrm{mmol}_{\mathrm{c}} / \mathrm{dm}^{3}$; sum of bases $=99.0 \mathrm{mmol}_{\mathrm{c}} / \mathrm{dm}^{3}$; cation exchange capacity $=127.5 \mathrm{mmol} / \mathrm{cm}^{3}$; base saturation $=$ $65.5 \%$, indicating adequate conditions of soil fertility for the forage grass species studied (Brachiaria brizantha (Hochst ex A. Rich) Stapf. cv Marandu) (Werner et al., 1996). The climate, according to Koppen, is the Cwa mesothermal humid subtropical of dry winter, with average temperatures lower than $18^{\circ} \mathrm{C}\left(12.5\right.$ to $\left.22.4^{\circ} \mathrm{C}\right)$ in the coldest month and higher than $22{ }^{\circ} \mathrm{C}\left(19.8\right.$ to $\left.27.9^{\circ} \mathrm{C}\right)$ during the summer. Climatic data during the experiment were collected in a Meteorological Station located at approximately $500 \mathrm{~m}$ from the experimental site (Figure 1).

Monitoring of sward surface height started soon after staging and was performed on a weekly basis until swards reached around $20 \mathrm{~cm}$, when the frequency of monitoring increased to twice a week until the end of the experiment. A total of 100 readings per paddock were recorded using a sward stick (Barthram, 1985). These were taken along four transect lines arranged in a zigzag format (25 points per transect). A tolerance range of $\pm 10 \%$ was established for

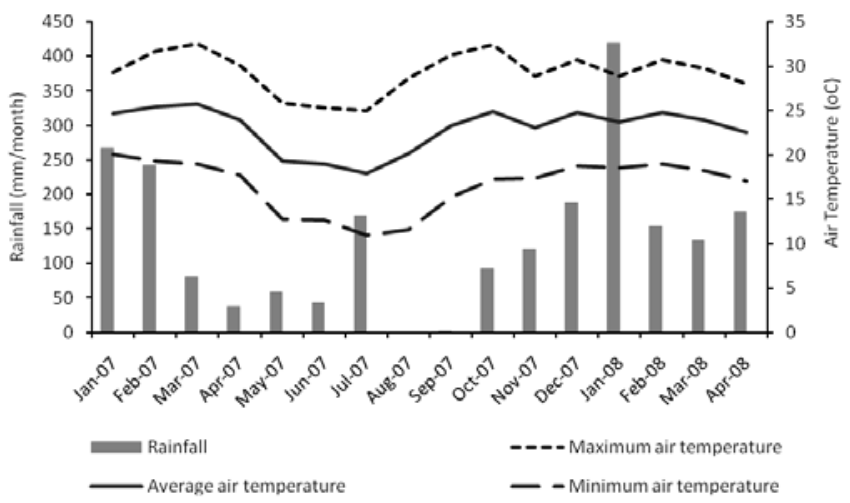

Figure 1 - Monthly means of rainfall and maximum, minimum and average air temperature of the experimental site from January 2007 to April 2008. variations around the target (27 to $33 \mathrm{~cm}$ ), and as the lower limit of the range was reached, animals started to be placed in paddocks, from Oct. 2006 onwards. Animals were added or removed from paddocks according to the need to maintain sward target relatively stable and around $30 \mathrm{~cm}$. Grazing was carried out by Nelore (Bos taurus indicus) and Canchim (3/8 Charolais - Bos taurus taurus $-\times 5 / 8 \mathrm{Zebu}-$ Bos taurus indicus - crossbred) heifers with an average initial body weight of 250 to $280 \mathrm{~kg}$. Variation in sward surface height throughout the experiment remained within the pre-specified range (30 $\mathrm{cm} \pm 10 \%)$, with an average of $29.7 \mathrm{~cm}( \pm 0.67)$ varying from 27.8 to $31.0 \mathrm{~cm}$. Stocking rate used to control grazing and maintain swards on target varied from 0.3 to 5.6 animal units/ha (1 AU = one adult animal weighing $450 \mathrm{~kg}$ ) throughout the year.

Treatments corresponded to the application of 150 , 300 and $450 \mathrm{~kg} / \mathrm{ha}$ of $\mathrm{N}$ plus the control (no fertilization) using pure ammonium nitrate. The total dose was applied in four equal dressings throughout the year in the following dates: Year 1 - Dec. 19, 2006; Jan. 16, 2007; Feb. 23, 2007 and Mar. 23, 2007; Year 2 - Dec. 20, 2007;Jan. 17, 2008; Feb. 14, 2008 and Mar. 13, 2008. The experimental design was of completely randomized block, with four replications. Evaluations were initiated only after all 16 paddocks (experimental units) had reached the sward target of $30 \mathrm{~cm}$ and were being continuously stocked by cattle, a condition that only happened from Dec. 2006 onwards. For that reason, the experimental period started only in Jan. 2007 and finished in Apr. 2008, comprising two entire consecutive pasture growing seasons (2006/2007 and 2007/2008).

Measurements relative to structural characteristics of tiller age categories were carried out in two opportunities throughout the year; one during fall/winter 2007 (Jun. 6 to Jul.30, 2007) and another during summer 2008 (Feb. 22 to Mar. 19, 2008), which were periods of low and high growth rates of plants, respectively (Mesquita et al., 2010). In order to perform this kind of evaluation, it was necessary to know the time of appearance of each tiller generation, which was the reason why measurements of this experiment were performed on tillers tagged every 28 days following a protocol for evaluating tiller dynamics and demography in a concomitant experiment in the same experimental area (Caminha et al., 2010). Three 30-cm diameter PVC rings were anchored at soil surface using metallic staples and all tillers inside the rings were labelled with single colored plastic coated wires at first tagging. From second the tagging onwards, new tillers were tagged using a new color, and the surviving ones were counted throughout the experimental period. Based on appearance dates, tillers were divided in 
three age categories: (1) Old - more than 4 months from tagging; (2) Mature - between 2 and 4 months from tagging; (3) Young-less than 2 months from tagging. Therefore, for the evaluations performed during fall/winter 2007, tiller age categories corresponded to: (1) Old - tillers tagged in January and February 2007; (2) Mature - tillers tagged in March and April 2007; (3) Young - tillers tagged in May and June 2007. For the evaluations performed during summer 2008, tiller age categories corresponded to: (1) Old - tillers tagged in October 2007 or before; (2) Mature -tillers tagged in November and December 2007; (3) Young-tillers tagged in January and February 2008. In all periods, six tillers from each age category were chosen per ring, totalling 72 tillers per treatment. These were identified using plastic rings and monitored once a week during fall/winter and twice a week during summer.

Selected tillers were classified as basal or aerial, intact or defoliated. Further, leaves were also classified as intact or defoliated, and had their lamina length measured according to their stage of development. On expanded leaves, length was measured from the tip of the leaf to its ligule. On expanding leaves the procedure was the same, except that the ligule of the last expanded leaf was used as reference. On senescing leaves, measurements were made from the ligule to the border line between the green and the yellow/brown-senescing tissue on the leaf lamina. The length of leaf sheath + stem (denominated only stem from this point onwards) was measured from the point of origin of the tagged tiller (soil level or point of insertion on the parent tiller for basal and aerial tillers, respectively) to the ligule of the last expanded leaf.

Data was used to calculate the structural characteristics of tillers for each age category, as follows:

Final lamina length of expanded leaves ( $\mathrm{cm})$-calculated as the sum of the average length of expanded leaves per tiller divided by the number of evaluated tillers;

Stem length $(\mathrm{cm})$ - calculated as the sum of stem length per tiller divided by the number of evaluated tillers;

Number of expanding, expanded and senescing leaves per tiller - calculated as the sum of expanding, expanded and senescing leaves per tiller divided by the number of tillers evaluated, respectively;

Number of live leaves per tiller - calculated as the sum of expanding, expanded and senescing leaves per tiller divided by the number of evaluated tillers. Senescing leaves in which more than $50 \%$ of lamina length had been impaired by senescence were discarded.

Data for each time of the year were analysed using the GLM procedure (Allison, 2005) of SAS $^{\circledR}$ (Statistical Analysis System). Treatment means were estimated using the "LSMEANS" command and comparisons, when appropriate, made with Tukey test at a 5\% significance level.

\section{Results and Discussion}

Forage grasses in pastures have a large capacity of adapting to defoliation strategies through progressive and reversible changes in their morphogenetic and structural characteristics (Lemaire \& Chapman, 1996). Pastures, as plant communities, are comprised of tillers in different stages of development, presenting at any one time tillers that have just appeared, tillers at variable stages of vegetative development and also tillers at their reproductive stage. In each developmental stage, plant structural characteristics may vary depending on local nutrient availability, physiological age of tillers (Bullock et al., 1994) and potential of response of such tillers to management practices (Pontes et al., 2010). In this study, the final length of expanded leaves and stem length varied only with tiller age category ( $P<0.0001$ for final length of expanded leaves and stem length in fall/winter and $\mathrm{P}=0.0020$ for final length of expanded leaves and $\mathrm{P}<0.0001$ for stem length in summer), with no response to nitrogen fertilization $(\mathrm{P}>0.05)$ (Table 1 ).

During fall/winter, mature tillers had longer final length of expanded leaves than young and old tillers (Table 1). According to Lemaire \& Chapman (1996), leaf length is the combined result of leaf elongation rate and leaf elongation duration, both influenced by leaf sheath length. As a consequence, the first leaves emerging from short pseudo stem tillers appear very quickly and are short; this changes to the reverse as pseudo stem length increases with tiller development. Such pattern of response is in line with the results of final length of expanded leaves recorded during fall/winter, since young tillers were at their early stages of development characterised by short stems, and old tillers

Table 1 - Final leaf length of expanded leaves and stem length (cm) of tiller age categories on continuously stocked marandu palisade grass maintained at $30 \mathrm{~cm}$ and fertilized with nitrogen in fall/winter 2007 and summer 2008

\begin{tabular}{lcccc}
\hline $\begin{array}{l}\text { Season of } \\
\text { the year }\end{array}$ & \multicolumn{3}{c}{ Tiller age category } & \multirow{2}{*}{ SEM } \\
\cline { 2 - 4 } & Young & Mature & Old & \\
\hline \multirow{2}{*}{ Fall/winter } & Final leaf length of expanded leaves & \\
Summer & $14.2 \mathrm{~B}$ & $19.9 \mathrm{~A}$ & $12.7 \mathrm{~B}$ & 0.55 \\
& $15.7 \mathrm{~A}$ & $16.1 \mathrm{~A}$ & $11.9 \mathrm{~B}$ & 1.22 \\
Fall/winter & 7.0C & Stem length & \\
Summer & $11.0 \mathrm{~B}$ & 13.0B & $18.0 \mathrm{~A}$ & 0.71 \\
\hline
\end{tabular}

SEM - Standard error of the mean.

Means followed by the same letter in rows are not different $(\mathrm{P}>0.05)$ by Tukey test. 
were at their reproductive stage, causing shortening of leaf sheath due to elevation of their apical meristem.

During summer, there was no difference in final length of expanded leaves between young and mature tillers, which had larger final length of expanded leaves than old tillers. Leaf size is the combined result of leaf appearance and elongation rate, with long leaves associated with high rates of leaf elongation and short leaves associated with high rates of leaf appearance (Cruz \& Boval, 2000). Therefore, rates of leaf appearance and elongation influence leaf size in opposite ways as a means of maintaining the structural characteristics of tillers and sward structure relatively stable. Further, there is an ontogenetic effect on morphogenetic characteristics of tillers, with young tillers having higher rates of leaf appearance and elongation than old tillers (Paiva et al., 2011). The fact indicates that in addition to stem length, the balance between leaf appearance and elongation is also an important factor determining the final length of leaves (Duru \& Ducrocq, 2000b). In the present study, during summer, young and mature tillers had similar final length of expanded leaves, suggesting that rates of leaf elongation for both tiller age categories compensated the effect of shorter stems on final leaf length.

As tillers develop, successive leaves take longer to appear and have longer final length of expanded leaves (Skinner \& Nelson, 1995). However, stem elongation elevates apical meristems of tillers, shortening the sheath of new leaves and resulting in shorter appearance intervals for leaves of higher level of insertion in tiller axis (Duru \& Ducrocq, 2000ab; Skinner \& Nelson, 1995), especially for tropical grass species (Da Silva \& Nascimento Júnior, 2007). Usually, old tillers are subjected to longer periods of competition for light, explaining their longer stems and short leaves relative to young tillers during both fall/winter and summer.

The number of live leaves per tiller was not affected by nitrogen fertilization $(\mathrm{P}>0.05)$, but varied with tiller age category ( $\mathrm{P}=0.0002$ in fall/winter and $\mathrm{P}<0.0001$ in summer) (Table 2). During fall/winter, the number of live leaves per tiller on mature tillers was larger than on young and old

Table 2 - Number of live leaves per tiller of different tiller age categories on continuously stocked marandu palisade grass maintained at $30 \mathrm{~cm}$ and fertilized with nitrogen in fall/winter 2007 and summer 2008

\begin{tabular}{lcccc}
\hline $\begin{array}{l}\text { Season of } \\
\text { the year }\end{array}$ & \multicolumn{3}{c}{ Tiller age category } & SEM \\
\cline { 2 - 4 } & Young & Mature & Old \\
\hline Fall/winter & $3.2 \mathrm{~B}$ & $3.8 \mathrm{~A}$ & $3.3 \mathrm{~B}$ & 0.13 \\
Summer & $4.0 \mathrm{~A}$ & $3.7 \mathrm{~B}$ & $3.1 \mathrm{C}$ & 0.15 \\
\hline
\end{tabular}

SEM - Standard error of the mean.

Means followed by the same letter in rows are not different $(\mathrm{P}>0.05)$ by Tukey test. ones, while in summer number of live leaves per tiller decreased as tillers became older. Number of live leaves per tiller is a relatively stable characteristic for a given plant genotype (Lemaire \& Chapman, 1996; Matthew et al., 2000). It is the result of the interaction between leaf appearance rate and leaf lifespan (Duru \& Ducrocq, 2000b; Lemaire \& Chapman, 1996), a condition that favors the existence of leaves of different developmental stages on a same tiller. However, depending on the stage of development and tiller age, the number of live leaves per tiller may vary. In the present study, during fall/winter, mature tillers showed larger number of live leaves per tiller than young and old tillers. The smaller number of live leaves per tiller for old tillers was the result of the lower number of expanding and larger number of senescing leaves (Table 3); both characteristics that varied only with tiller age category $(\mathrm{P}<0.0001)$. For young tillers, the smaller number of live leaves per tiller was the result of a smaller number of senescing leaves, since there was no difference in the number of expanded leaves per tiller between tiller age categories (average of 1.6 expanded leaves per tiller). The greater number of live leaves per tiller for mature tillers was due to the big number of expanding, senescing and expanded (1.9 leaf/tiller) leaves for that tiller age category. Old tillers are characterized by low rates of leaf appearance relative to mature and young tillers (Duru \& Ducrocq, 2000b), which result in smaller number of expanding leaves with longer leaf lifespan, a condition associated with bigger number of senescing leaves. On the other hand, young tillers have higher rates of leaf appearance and shorter live leaves (Paiva et al., 2011), while mature tillers show intermediate behaviour between young and old tillers.

During summer, number of live leaves per tiller was not affected by nitrogen fertilization ( $\mathrm{P}>0.05)$. However, the number of expanding leaves per tiller varied with the nitrogen fertilization $\times$ tiller age category interaction $(\mathrm{P}=0.0310)$ (Figure 2), with smaller numbers recorded for old tillers as nitrogen application rate increased, except for the nonfertilized swards. This fact may be related with the difference between chronological and physiological age of monitored

Table 3 - Number of expanding and senescing leaves per tiller of different tiller age categories on continuously stocked marandu palisade grass maintained at $30 \mathrm{~cm}$ and fertilized with nitrogen in fall/winter 2007

\begin{tabular}{lcccc}
\hline Characteristic & \multicolumn{3}{c}{ Tiller age category } & \multirow{2}{*}{ SEM } \\
\cline { 2 - 4 } & Young & Mature & Old & \\
\hline Expanding leaves & $1.30 \mathrm{~A}$ & $1.34 \mathrm{~A}$ & $1.16 \mathrm{~B}$ & 0.03 \\
Senescing leaves & $0.22 \mathrm{~B}$ & $0.50 \mathrm{~A}$ & $0.51 \mathrm{~A}$ & 0.02 \\
\hline
\end{tabular}

SEM - Standard error of the mean.

Means followed by the same letter in rows are not different $(\mathrm{P}>0.05)$ by Tukey test. 
tillers. On fertilized swards, tillers tagged as old (more than 4 months of tagging) could be physiologically older than those on non-fertilized or fertilized with lower rates of nitrogen, a consequence of the direct influence nitrogen exerts in accelerating cell flows in meristematic zones (MacAdam et al., 1989).

The number of senescing leaves per tiller varied only with nitrogen fertilization ( $\mathrm{P}=0.0017$ ) (Figure 3), with larger values recorded on swards fertilized with 300 and $450 \mathrm{~kg} / \mathrm{ha}$. Such effect is probably related to the positive influence nitrogen has on cell metabolism, increasing cell flows and consequently the rhythm of initiation and senescence of leaves (Schnyder et al., 2000). Tiller age may interfere with the strategy plants use to persist in grazed communities (Bullock et al., 1994). Young tillers have high leaf elongation rates as a means of allowing for high rates of growth, a typical response associated with resource capture

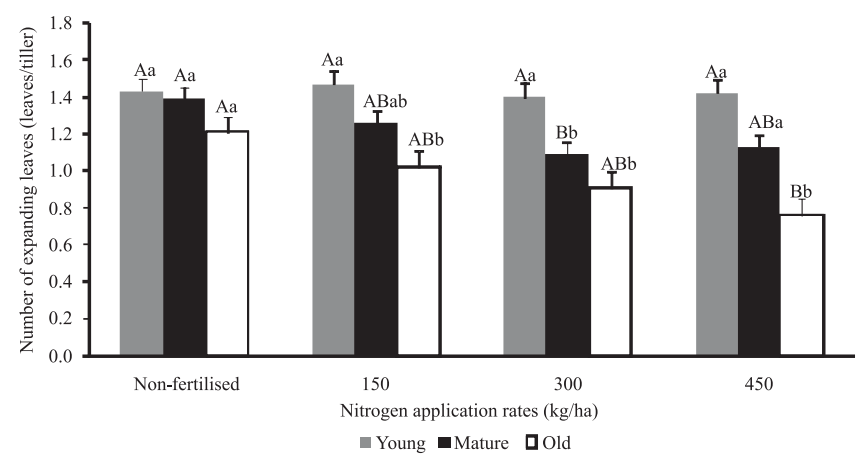

Upper case letters compare nitrogen fertilization treatments within tiller age category.

Lower case letters compare tiller age categories within nitrogen fertilization treatments.

Figure 2 - Number of expanding leaves per tiller according to tiller age categories on continuously stocked marandu palisade grass maintained at $30 \mathrm{~cm}$ and fertilized with nitrogen in summer 2008.

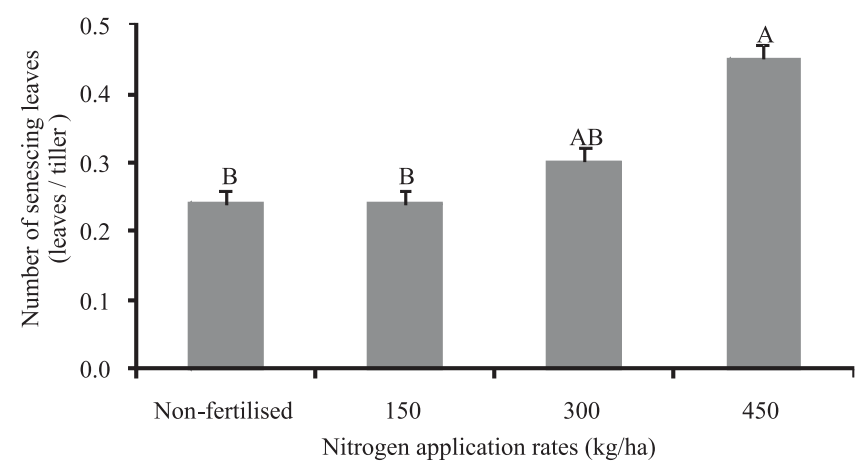

Figure 3 - Number of senescing leaves per tiller according to tiller age categories on continuously stocked marandu palisade grass maintained at $30 \mathrm{~cm}$ and fertilized with nitrogen in summer 2008. strategies. In spite of their shorter pseudo stem (Table 1), they possibly show high rates of leaf appearance and elongation in response to nitrogen fertilization, which explains the larger number of expanding and long expanded leaves (Tables 1 and 3). On the other hand, old tillers seem to rely on resource conservation strategies, even under conditions of high availability of nitrogen (Figure 2). Even though nitrogen promoted changes in the number of senescing and expanding leaves per tiller, during summer, the number of live leaves per tiller varied only with tiller age category (Table 2).

Recent series of experiments with marandu palisade grass carried out concomitantly to this experiment in the same experimental area demonstrated that nitrogen fertilization increased the turnover of tiller population by accelerating rates of tiller appearance and death (Caminha et al., 2010) and resulted in larger proportions of leaves in sward herbage mass as well as larger sward leaf area index on swards maintained at the same height (Mesquita et al., 2010). Therefore, tiller age interfered significantly on tiller structural characteristics, resulting in variations in sward structure with potential implications to plant and animal responses (Hodgson \& Da Silva, 2002). The fact opens a new window of opportunities for planning and definition of grazing management practices and the use of fertilizers and irrigation in pastures through manipulation of aspects related to the dynamics of tiller population and perennation strategy used by plants.

\section{Conclusions}

Tiller age is an important factor interfering with structural characteristics and may influence plant and animal responses on pastures by altering sward structure.

\section{References}

ALEXANDRINO, E.; NASCIMENTO JÚNIOR, D.; MOSQUIM, P.R. et al. Características morfogênicas e estruturais na rebrotação da Brachiaria brizantha cv. marandu submetida a três doses de nitrogênio. Revista Brasileira de Zootecnia, v.33, n.6, p.1372-1379, 2004.

ALLISON, P.D. Fixed effects regression methods for longitudinal data using SAS. Cary: SAS Institute, 2005. 148 p.

BULLOCK, J.M.; MORTIMER, A.M.; BEGON, M. Physiological integration among tillers of Holcus lanatus: age dependence and responses to clipping and competition. New Phytologist, v.128, n.4, p.737-747, 1994.

CAMINHA, F.O.; DA SILVA, S.C.; PAIVA, A.J. et al. Estabilidade da população de perfilhos de capim-marandu sob lotação contínua e adubação nitrogenada. Pesquisa Agropecuária Brasileira, v.45, n.2, p.213-220, 2010.

CRUZ, P.; BOVAL, M. Effect of nitrogen on some morphogenetic traits of temperate and tropical perennial forage grasses. 
In: LEMAIRE, G.; HODGSON, J.; MORAES, A. (Eds.) Grassland ecophysiology and grazing ecology. Wallingford: CABI Publishing, 2000. p.151-168.

DA SILVA, S.C.; NASCIMENTO JÚNIOR, D. Avanços na pesquisa com plantas forrageiras tropicais em pastagens: características morfofisiológicas e manejo do pastejo. Revista Brasileira de Zootecnia, v.36, p.121-138, 2007 (supl. especial).

DA SILVA, S.C.; BUENO, A.A.O.; CARNEVALLI, R.A. et al. Sward structural characteristics and herbage accumulation of Panicum maximum cv. mombaça subjected to rotational stocking managements. Scientia Agricola, v.66, n.1, p.8-19, 2009.

DURU, M.; DUCROCQ, H. Growth and senescence of the successive leaves on a tiller. effects of nitrogen and cutting regime. Annals of Botany, v.85, n.5, p.645-653, 2000a.

DURU, M.; DUCROCQ, H. Growth and senescence of the successive grass leaves on a tiller. Ontogenic development and effect of temperature. Annals of Botany, v.85, n.5, p.635-643, 2000b.

EMPRESA BRASILEIRA DE PESQUISA AGROPECUÁRIA EMBRAPA. Sistema brasileiro de classificação de solos. Brasília: EMBRAPA Produção de Informação, 1999. 412p.

GARCEZ NETO, A.F.; NASCIMENTO JÚNIOR, D.; REGAZZI, A.J. et al. Respostas morfogênicas e estruturais de Panicum maximum cv. Mombaça sob diferentes níveis de adubação nitrogenada e alturas de corte. Revista Brasileira de Zootecnia, v.31, n.5, p.1890-1900, 2002.

HODGSON, J. Grazing management: science into practice. New York: John Wiley; Longman Scientific and Technical, 1990. 203p.

HODGSON, J.; DA SILVA, S.C. Options in tropical pasture management. In: REUNIÃO ANUAL DA SOCIEDADE BRASILEIRA DE ZOOTECNIA, 39., 2002, Recife. Anais... Recife: Sociedade Brasileira de Zootecnia, 2002. p.180-202.

LEMAIRE, G. Ecophysiology of grasslands: dynamic aspects of forage plant populations in grazed swards. In: INTERNATIONAL GRASSLAND CONGRESS, 19., 2001 São Pedro. Proceedings... Piracicaba: FEALQ, 2001. p.29-37.

LEMAIRE, G.; CHAPMAN, D. Tissue flows in grazed plant communities. In: HODGSON, J.; ILLIUS, A.W. (Eds.). The ecology and management of grazing systems. London: CAB International, 1996. p.3-36.

LEMAIRE, G.; AGNUSDEI, M. Leaf tissue turn-over and efficiency of herbage utilization. In: LEMAIRE, G.; HODGSON, J.; MORAES, A. et al. (Eds.) Grassland ecophysiology and grazing ecology. Wallingford: CAB International, 2000. p.265-288.

MacADAM, J.W.; VOLENEC, J.J.; NELSON, C.J. Effects of nitrogen on mesophyll cell division and epidermal cell elongation in tall fescue leaf blades. Plant Physiology, v.89, n.2, p.549-556, 1989.
MARTUSCELLO, J.A.; FONSECA, D.F.; NASCIMENTO JÚNIOR, D. et al. Características morfogênicas e estruturais de capim-massai submetido a adubação nitrogenada e desfolhação. Revista Brasileira de Zootecnia, v.35, n.3, p.665-671, 2006.

MATTHEW, C.; ASSUERO, S.G.; BLACK, C.K. et al. Tiller dynamics of grazed swards. In: LEMAIRE, G.; HODGSON, J.; MORAES, A. et al. (Eds.) Grassland ecophysiology and grazing ecology. Wallingford: CAB International, 2000. p.127-150.

MESQUITA, P.; DA SILVA, S.C.; PAIVA, A.J. et al. Structural characteristics of marandu palisade grass swards subjected to continuous stocking and contrasting rhythms of growth. Scientia Agrícola, v.67, n.1, p.23-30, 2010.

MORAIS, R.V.; FONSECA, D. M.; NASCIMENTO JÚNIOR, D. et al. Demografia de perfilhos basilares em pastagem de Brachiaria decumbens adubada com nitrogênio. Revista Brasileira de Zootecnia, v.35, n.2, p.380-388, 2006.

PAIVA, A.J.; DA SILVA, S.C.; PEREIRA, L.E.T. et al. Morphogenesis on age categories of tillers in marandu palisadegrass. Scientia Agrícola, v.68, n.6, p.626-631, 2011.

OMETTO, J.C. Bioclimatologia vegetal. São Paulo: Agronômica Ceres, 1981. 425p.

PONTES, L.S.; LOUAULT, F.; CARRÈRE, P. et al. The role of plant traits and their plasticity in the response of pasture grasses to nutrients and cutting frequency. Annals of Botany, v.105, n.6, p.957-965, 2010.

SANTOS, P.M.; CORSI, M.; PEDREIRA, C.G.S. et al. Tiller cohort development and digestibility in Tanzania guinea grass (Panicum maximum cv. Tanzania) under three levels of grazing intensity. Tropical Grassland, v.40, n.1, p.84-93, 2006.

SBRISSIA, A.F.; DA SILVA, S.C. O ecossistema de pastagens e a produção animal In: REUNIÃO ANUAL DA SOCIEDADE BRASILEIRA DE ZOOTECNIA, 38., 2001, Piracicaba. Anais... Piracicaba: Sociedade Brasileira de Zootecnia, 2001. p.731- 754.

SCHNYDER, R.H.; SCHÄUFELE, R.; VISSER, R. et al. An integrated view of $\mathrm{c}$ and $\mathrm{n}$ uses in leaf growth zones of defoliated grasses. In: LEMAIRE, G.; HODGSON, J.; MORAES, A. et al. (Eds.) Grassland ecophysiology and grazing ecology. Wallingford: CABI Publishing, CAB International, 2000. p.41-60.

SKINNER, R.H.; NELSON, C.J. Elongation of the grass leaf and its relationship to the phyllochron. Crop Science, v.35, n.1, p.4-10, 1995.

WERNER, J.C.; PAULINO, V.T.; CANTARELLA, H. Forrageiras In: RAIJ, B.V.; CANTARELLA, H.; QUAGGIO, J.A. et al. (Eds.) Recomendações de adubação e calagem para o Estado de São Paulo. Campinas: Instituto Agronômico, 1996. p.263-273 (Boletim técnico, 100). 